\title{
Pengembangan Minat Baca Siswa Berbasis Psikologi Pendidikan Islam di Sekolah Dasar
}

\author{
${ }^{1}$ Mulyadi, ${ }^{2}$ Alef Theria Wasem, ${ }^{3}$ Arif Budi Raharjo, ${ }^{4}$ Fitriah M. Suud \\ ${ }^{1234}$ Universitas Muhammadiyah Yogyakarta \\ Email: fitriahmsuud@gmail.com
}

\begin{abstract}
Reading is opening the window of the world, finding lots of knowledge and opening up one's insights. So reading is the most important thing in education, but the fact is children's interest in reading, especially in Indonesia is still very minimal. This study aims to find out how parenting was developed by parents of students who excel at the As-Shafa Islamic Elementary School in Pekanbaru, Riau in increasing children's reading interest. The research method used in this study was qualitative phenomenology, data collection was carried out through interviews and interactive documentation in three components of analysis, namely data reduction, data presentation, and conclusions. The results obtained in the study that the majority of parents of outstanding students are busy working but still taking the time to give love, protection, guidance, accompany children in learning, direction and education in daily life. While the patterns found are mostly using democratic and situational patterns. This research suggests that parents maintain the quality of attachment with children and spend a lot of time in accompanying them to learn.
\end{abstract}

Keywords: Interest In Reading, Parenting, Psychology Of Islamic Education, High Achieving Children

\section{Pendahuluan}

Membaca adalah jendela dunia, merupakan pintu pembuka pengetahuan, membangun peradaban dan meninggikan akhlak, moralitas dan nilai-nilai kemanusiaan. Kegiatan membaca menjadi inti dan dasar aktifitas pendidikan sehingga membaca seharusnya menjadi tradisi dan atau kebiasaan masyarakat Islam dimana pun mereka berada. Wahyu pertama yang diturunkan Allah kepada Nabi Muhammad SAW, melalui perantaraan malaikat Jibril dalam Al-Qur'an adalah Surat Al'Alaq, yakni perintah "membaca", bahkan ketika Rasulullah saat itu belum dan tidak tahu baca-tulis. Turunnya surah pertama Al-Qur'an menegaskan bahwa membaca, menjadi tanda esksistensial kenabian dan kerasulan Muhammad SAW yang diutus ke dunia, selain sebagai penyempurna akhlak yang luhur juga sebagai pendidik umat manusia ${ }^{1}$.

Menurut Nurcholish Madjid, saat ini umat Islam membutuhkan suatu kerangka berfikir (intellectual framework) yang bersifat menyeluruh dan sistematis. Kerangka berfikir itu harus dapat dilihat dengan jelas peta pandangan hidup Muslim secara bulat dan dapat diterangkan hubungan suatu pandangan tertentu dengan keseluruhan konsepsi Islam. Al-Qur'an sebagai sumber ajaran yang membuka kemungkinan bagi umat Islam demi tersusunnya kerangka fikir yang menyeluruh ${ }^{2}$. Kerangka pikir yang menyeluruh

\footnotetext{
${ }^{1}$ Achmadi, Islam Sebagai Paradigma Ilmu Pengetahuan (Yogyakarta: Aditya Media, 1992).

2 Rusydi Hamka and Iqbal Emsyarif Saimima, Kebangkitan Islam Dalam Pembahasan (Jakarta: Nurul Islam, 1980).
} 
dibentuk melalui pendidikan, yakni dengan kegiatan membaca sebagai suatu keharusan yang tidak bisa ditawar-tawar.

Membaca memberi berjuta manfaat, sayangnya saat ini minat baca masyarakat Muslim Indonesia tergolong sangat rendah dan memprihatinkan. Terlebih di zaman modern ini, waktu dan hari-hari anak-anak lebih banyak dihabiskan untuk bermain game oline serta asyik dengan media sosial, ketimbang mengaji (membaca Al-Qur'an) serta membaca buku-buku ilmu pengetahuan dan keislaman. Di lain sisi, karena kesibukan kerja harian, menjadikan banyak orang tua yang abai dan tidak peduli dengan aktivifas anak-anaknya, banyak orang tua tidak memotivasi anak-anaknya gemar membaca atau meningkatkan minat baca. Bahkan orang tua tidak memiliki kekuatan penuh dalam memerankan dirinya untuk mengembangkan minat baca anak.

Hasil survey menunjukkan secara umum minat baca masyarakat Indonesia masih tergolong rendah. Bahkan terendah di antara masyarakat di negara ASEAN. Tahun 2006 berdasarkan data Badan Pusat Statistik menunjukan, masyarakat Indonesia belum menjadikan kegiatan membaca sebagai sumber utama mendapatkan informasi. Masyarakat lebih memilih menonton televisi (85,9\%), mendengarkan radio (40,3\%) daripada membaca koran (23,5\%). Tahun 2009, budaya baca masyarakat Indonesia menempati posisi terendah dari 52 negara di kawasan Asia Timur (OECD). Tahun 2011 berdasarkan survei UNESCO rendahnya minat baca, dibuktikan dengan indeks membaca masyarakat Indonesia hanya 0,001 (dari seribu penduduk, hanya ada satu orang yang masih memiliki minat baca tinggi).

Tahun 2012 Indonesia menempati posisi 124 dari 187 Negara dunia dalam penilaian Indeks Pembangunan Manusia (IPM), khususnya terpenuhinya kebutuhan dasar penduduk, termasuk kebutuhan pendidikan, kesehatan dan 'melek huruf. Indonesia sebagai Negara berpenduduk 165,7 juta jiwa lebih, hanya memiliki jumlah terbitan buku sebanyak 50 juta per tahun. Itu artinya, rata-rata satu buku di Indonesia dibaca oleh lima orang ${ }^{3}$. Sementara itu berdasarkan studi lima tahunan yang dikeluarkan oleh Progress in International Reading Literacy Study (PIRLS) pada tahun 2006, yang melibatkan siswa sekolah dasar (SD), hanya menempatkan Indonesia pada posisi 36 dari 40 negara yang dijadikan sampel penelitian. "Posisi Indonesia itu lebih baik dari Qatar, Kuwait, Maroko, dan Afrika Selatan," Sedangkan berdasarkan penelitian Human Development Index (HDI) yang dikeluarkan oleh UNDP untuk melek huruf pada 2002 menempatkan Indonesia pada posisi 110 dari 173 negara. Posisi tersebut kemudian turun satu tingkat menjadi 111 di tahun $2009{ }^{4}$. Di Indonesia minat baca yang rendah tidak hanya terjadi pada masyarakat umum, tetapi juga pada siswa-siswa sekolah.

\footnotetext{
Mardiah, 'Menumbuhkan Minat Baca | IBLiMS', IBLiMs, 2014 <http://bpsdmkp.kkp.go.id/apps/perpustakaan/?q=node/23> [accessed 28 October 2019].

4 Anissa Mutia and Endro Yuwanto, Minat Baca Anak Indonesia Memprihatinkan | Republika Online', Republika, 2010 <https://www.republika.co.id/berita/pendidikan/berita/10/07/07/123680minat-baca-anak-indonesia-memprihatinkan> [accessed 28 October 2019].
} 
Banyak aspek yang menjadi akar penyebab dan permasalahan rendahnya minat baca anak ${ }^{5}$. Kasus di dalam kehidupan keluarga, terkadang orang tua tidak mengetahui bagaimana caranya harus memerankan dirinya dalam mengasuh anak-anaknya. Bahkan ada orang tua tidak memahami kalau di dalam dirinya melekat peran utama dalam memberikan pembinaan mengembangkan minat baca anak. Akibatnya orang tua banyak menyerahkan peran tersebut semata-mata kepada guru di sekolah. Dari situasi ketidakmengertian dan ketidakmampuan orang tua ini, akibatnya berdampak pada dilema psikologis anak, ketika anak harus beradaptasi dan bersosialisasi dalam kehidupan keluarga dan masyarakatnya ${ }^{6}$. Anak-anak menjadi canggung dan bahkan kebingungan, tidak mengerti apa yang musti dikerjakan. Selain itu karena ketidakmengertian dan ketidakmampuan orang tua dalam mengasuh dan mengembangkan minat baca anak, berimbas pula pada perkembangan pendidikannya di sekolah maupun di tengah-tengah masyarakat ${ }^{7}$. Lebih ironis, dengan kurangnya tradisi minat baca berimbas dalam perkembangan psikologi anak. Selain itu yang paling jelas dampak kurangnya minat baca adalah anak tidak memiliki bekal pengetahuan, kekuatan serta kemampuan untuk menatap dan mengisi masa depannya.

Persoalan membaca di Provinsi Riau belum begitu menjadi bagian penting bagi keluarga. Berbagai penelitian dan data menunjukkan bahwa peningkatan minat baca di Provinsi Riau belum menunjukkan data yang menggembirakan. Hal ini disebabkan oleh berbagai faktor, antara lain karena akses terhadap sumber bacaan yang sulit terjangkau, adanya daerah-daerah terisolir yang sulit diakses dengan alat transportasi. Disamping itu, sarana yang disediakan pemerintah untuk memotivasi masyarakat agar tergugah keinginannya untuk membaca juga sangat minim. Dari berbagai sekolah yang ada di Riau, SD Islam As-Shofa memiliki keunikan tersendiri untuk diteliti. SD Islam As-Shofa memiliki program dan layanan kepada siswanya agar sejak awal memasuki sekolah ini ditumbuhkan minat baca.

Dari tumbuhnya minat baca ini menjadikan siswa di Sekolah ini saling berlomba untuk meningkatkan prestasi akademik maupun prestasi non akademik. Pola yang diterapkan orang tua dalam memposisikan dirinya agar berperan utuh dan mutlak dalam mengoptimalkan tumbuhnya minat baca anak, orang tua perlu kehatian-hatian agar maksud baik yang diinginkan tidak menjadi sebab anak malas bahkan anti dengan bahan bacaan. Karena itu sangat perlu digali informasi dari orang tua model pola asuh yang

5 Ming Ming Chiu, 'Contextual Influences on Girls' and Boys' Motivation and Reading Achievement: Family, Schoolmates, and Country' (Springer, Cham, 2018), pp. 49-63 <https://doi.org/10.1007/978-3-319-75948-7_3>; Qishan Chen and others, 'Effects of Socioeconomic Status, Parent-Child Relationship, and Learning Motivation on Reading Ability.', Frontiers in Psychology, 9 (2018), 1297 < https://doi.org/10.3389/fpsyg.2018.01297>.

6 Mehmet Firat, Hakan Kilınç, and Tevfik Volkan Yüzer, 'Level of Intrinsic Motivation of Distance Education Students in E-Learning Environments', Journal of Computer Assisted Learning, 34.1 (2018), 63-70 <https://doi.org/10.1111/jcal.12214>.

7 Mehmet Ülger, Süleyman Yiğittir, and Orhan Ercan, 'Secondary School Teachers' Beliefs on Character Education Competency', Procedia - Social and Behavioral Sciences, 131 (2014), 442-49 <https://doi.org/10.1016/J.SBSPRO.2014.04.145>. 
diterapkan dalam mendidiknya yang dapat memberikan konstribusi berarti dalam menumbuhkan atau sebaliknya mematikan minat baca anak.

Melihat prestasi yang dicapai sekolah Sekolah Dasar Islam As-Shofa, baik prestasi siswa, maupun prestasi guru, maka keadaan tersebut memperlihatkan bahwa Sekolah Dasar Islam As-Shofa telah memberikan konstribusi yang signifikan dalam memicu tumbuhnya minat baca anak. Beranjak dari teori bahwa prestasi seorang anak dipengaruhi oleh keluarganya maka penelitian ini memberikan fokus pada bagaimana orangtua siswa-siswa yang berprestasi dan memiliki minat baca ini mendidik mereka. Oleh karena itu penelitian ini menjadi penting untuk dilakukan untuk memberikan kontribusi lebih terhadap peningkatan minat baca anak.

\section{Metode Penelitian}

Penelitian ini merupakan penelitian kualitatif yang mengacu kepada studi kasus tunggal yang terpancang karena hanya satu permasalahan yang diangkat dan pada satu tempat, sedangkan fokus penelitian sudah ditentukan dalam proposal sebelum peneliti terjun ke lapangan. Adapun level lain yang juga mendapatkan perhatian dalam penelitian ini adalah upaya pengembangan minat baca anak yang dilakukan oleh keluarga Muslim yang anaknya sekolah di SD Ash-Shofa Pekanbaru Riau, Suatu Tinjaun Psikologi Pendidikan Islam. Kerja peneliti tidak semata-mata memberikan gambaran tentang fenomena, akan tetapi juga membuat prediksi untuk mendapatkan makna dan implikasi dari suatu masalah yang akan dipecahkan.

\section{a. Sumber Data dan pengumpulan data}

Ada dua jenis sumber data yang digunakan dalam penelitian ini. Sumber data pertama adalah informasi dari hasil wawancara. Mereka adalah orang tua muslim yang anaknya sekolah di SD Islam Ash-Shofa Pekanbaru Riau. Adapun sumber data yang kedua adalah dokumentasi yang berasal dari SD Islam AshShofa. Dokumentasi Orang Tua berupa profil orang tua secara umum, serta profil informan penelitian. Informan penelitian yakni orang tua dan anak didik yang sekolah di SD Islam As-Shofa Pekanbaru Riau, dalam penelitian ini dibuat inisisal atau singkatan nama berdasarkan keluarga yang terdiri dari orang tua dan anak. Teknik sampling yang dipilih adalah purposive sampling, yaitu suatu teknik penentuan sampel untuk tujuan tertentu. Teknik pengumpulan data dilakukan dengan cara wawancara, observasi, focus group discussion, content analysis, dan kuesioner. Peneliti melakukan pengamatan terhadap aktivitas orang tua dalam kegiatan melakukan pengembangan minat baca anak.

\section{b. Teknik Analisis Data}

Analisis data dilakukan secara serempak dengan pengumpulan data, interpretasi data dan menulis laporan penelitian. Dengan demikian analisis data tidak dilakukan secara terpisah dengan pengumpulan data. Tetapi merupakan kegiatan yang dilakukan bersama-sama. Selama pengumpulan data, peneliti bergerak secara interaktif dalam tiga komponen analisis yaitu reduksi data, sajian data, dan simpulan akhir atau verifikasi. 


\section{Hasil Penelitian}

Penelitian ini dilakukan terhadap 8 keluarga yang anaknya berprestasi di SD asShofa. Setiap keluarga memiliki latarbelakang pendidikan yang berbeda dan juga aktivitas keseharian yang berbeda-beda. Wawancara ditujukan untuk mengetahui bagaimana pola asuh mereka dalam meningkatkan minat baca anak-anaknya yang berprestasi di sekolah. Hasil penelitian menunjukkan walaupun pola yang dibangun hamper memiliki kesamaan beberapa keluarga namun secara spesifik tetap memiliki keunikan tersendiri.

Tabel 1.

Pola Asuh Orang Tua di SD Islam Ash-Shofa Pekanbaru Riau

\begin{tabular}{|c|c|c|c|c|c|c|}
\hline \multirow[t]{2}{*}{ No } & \multirow{2}{*}{ Informan } & \multicolumn{4}{|c|}{ Penerapan Pola Asuh } & \multirow[t]{2}{*}{ Ket } \\
\hline & & $\mathbf{A}$ & $\mathbf{B}$ & $\mathbf{C}$ & $\mathbf{D}$ & \\
\hline 1 & $\mathrm{Fa}$ & & $\sqrt{ }$ & & $\sqrt{ }$ & 2 \\
\hline 2 & $\mathrm{Fh}$ & & $\sqrt{ }$ & & $\sqrt{ }$ & 2 \\
\hline 3 & Gt & & $\sqrt{ }$ & & $\sqrt{ }$ & 2 \\
\hline 4 & $\mathrm{Mr}$ & $\sqrt{ }$ & & & & 1 \\
\hline 5 & $\mathrm{Mp}$ & & $\sqrt{ }$ & & $\sqrt{ }$ & 2 \\
\hline 6 & $\mathrm{Nh}$ & & $\sqrt{ }$ & & $\sqrt{ }$ & 2 \\
\hline 7 & $\mathrm{Rf}$ & & $\sqrt{ }$ & & & 1 \\
\hline 8 & $\mathrm{Ry}$ & & $\sqrt{ }$ & & $\sqrt{ }$ & 2 \\
\hline
\end{tabular}

Keterangan:
A. Pola asuh Otoriter
B. Pola asuh Demokratis
C. Pola asuh Permisif
D. Pola asuh Situasional

Tabel di atas dapat dijelaskan, bahwa enam informan penelitian yaitu: Fa, Fh, Gt, $\mathrm{Mp}$, Nh, Ry telah menerapkan pola yang bersamaan, sama-sama tidak menerapkan pola otoriter, tidak pula sepenuhnya menerapkan pola demokratis. Karena bagi mereka ada beberapa aspek dari pola demokratis yang dapat diterapkan dalam mengembangkan minat baca anak. Sementara itu ke enam informan ini, sama-sama menyetujui dan telah menerapkan pola asuh situasional. Sedangkan informan $\mathrm{Mr}$ menolak pola asuh demokratis, permisif dan situasional, karena bagi Mr, pola yang paling sesuai untuk dapat mengembangkan minat baca anak hanyalah pola asuh Otoriter. Informan Rf menerapkan hal yang sebaliknya, menolak pola asuh otoriter, permisif dan situasional. Bagi Rf pola asuh yang tepat dalam mengembangkan minat baca anak adalah pola asuh demokratis. Kesimpulan yang tertera pada table di atas diperoleh dari analisi peneliti terhadap hasil wawancara dengan informan. Untuk mengetahui perbedaan secara jelas tentang pola asuh yang diterapkan oleh setiap keluarga tersebut dapat di sampaikan penjelasan lebih rinci. 


\section{Informan Fa}

Fa termasuk seorang ibu yang sangat peduli terhadap pendidikan anak-anaknya. Sekalipun ibu Fa bekerja dan punya usaha sendiri, Ibu Fa, selalu menyempatkan diri untuk memperhatikan pendidikan anak-anaknya, bagaimana proses belajar anak-anak di rumah, melakukan komunikasi dengan guru-guru anak-anaknya. Juga menyempatkan diri datang ke sekolah, maupun melalui komunikasi dengan menggunakan handphone. Disamping pola mengontrol yang rutin dan disiplin kepada anak-anaknya, disela kesibukan ibu $\mathrm{Fa}$ selalu menyediakan waktu untuk menemani anak-anaknya yang membutuhkan pembelian perlengkapan sekolah, terutama mengajak menemani anakanaknya ke toko buku. Walaupun dalam pelaksanaannya, ibu Fa, tidak dapat sepenuhnya menemani anak-anaknya, disebabkan waktu ibu $\mathrm{Fa}$ yang lebih banyak tersita untuk pekerjaan. Namun, walaupun demikian ibu Fa, tetap berupaya mencari waktu untuk anak-anaknya baik menemani bermain terlebih lagi berbelanja buku ke toko. Bagi ibu Fa, kepentingan pendidikan anak-anak merupakan keharusan mutlak yang tidak dapat ditawar-tawar. Berkaitan dengan hal ini, ibu Fa memberikan penjelasan, dapat disimpulkan:

"Upaya untuk. mengembangkan minat baca anak. memang menjadi keharusan yang mesti dijalankan oleh orang tua. Karena melalui kecintaan dan kasib sayang terhadapnya akan melabirkan kecintaan terhadap bacaan akan menjadikan anak mencintai ilmu, dengan mencintai ilmu merupakan pintu masuk bagi anak untuk dapat dengan mudah dihebatkan oleh orang tua, dihebatkan oleh sekolah, maupun kemampuannya dalam mengoptimalkan potensi dirinya dalam bidup bermasyarakat. Maka kemampuan orang tua dalam menyesuaikan berbagai potensi yang ada dengan potensi anak. menjadi keharusan yang barus ditetapkan".

Keluarga Fa menerapkan dua pola pengasuhan secara bersamaan, yakni pola pengasuhan demokratis dan situasional dalam kegiatan pengasuhan anak-anak mereka di rumah. Ada perbedaan antara teori pola asuh dengan kegiatan pengasuhan yang diterapkan keluarga Fa. Perbedaan dan kelebihan kegiatan pengasuhan yang diterapkan keluarga Fa dengan memberikan kasih sayang yang mendalam dan memberikan fasilitas buku bacaan untuk anak. Berdasarkan wawancara kepada infoman menurutnya upaya yang dilakukan untuk menunjang prestasi anak adalah dengan dua cara. Cara (1) lewat keluarga, upaya yang dilakukan orang tua untuk meningkatkan prestasi belajar anaknya antara lain: (a) mengawasi kegiatan belajar atau mendampingi belajar dan penggunaan waktu belajar anak, (b) menanamkan kebiasaan membaca, (c) mendatangkan guru privat kerumah. Cara (2) melalui sekolah, yakni antara orang tua dan pihak sekolah sering berkomunikasi melalui telpon dan orang tua sering menghadiri program orang tua mengajar yang dilaksanakan disekolah. 


\section{Informan Fh}

Fh adalah seorang security perempuan yang bekerja di sekolah dimana anaknya belajar. Pada mulanya sebagai seorang ibu bekerja sebagai securty apalagi di sekolah tempat anaknya belajar, bagi ibu Fh terasa berat, tetapi karena ini panggilan hatinya, ibu Fh merasa yakin dia mampu bekerja dengan tetap memberikan perhatian kepada anaknya. Pola asuh keluarga Fh dalam membangun pengembangan minat baca anak, lebih lanjut Fh memberikan penjelasan:

"Menerapkan pola pengasuban dan pembimbingan kepada anak agar memiliki kegemaran dalam membaca perlu memperbatikan berbagai situasi, baik situasi yang terjadi pada anak, maupun situasi yang dimiliki oleh orang tua. Saya di rumah telah lama menerapkan model seperti itu, saya memang ingin anak membaca bahan-bahan bacaan Islami, tetapi ketika saya melihat anak saya juga butub bacaan-bacaan umum, saya juga membeli buku-bukunya yang bervariasi”.

Keluarga Fh menerapkan pola pengasuhan demokratis dan situasional dalam kegiatan pengasuhan mereka di rumah. Ada perbedaan teori pola asuh dengan penerapan kegiatan pengasuhan keluarga Fh. Perbedaan dan kelebihan kegiatan pengasuhan dari keluarga Fh ialah dengan memberikan kasih sayang mendalam kepada anak, membimbing dan mendampingi anak saat belajar, serta memahami kebutuhan anak. Berdasarkan wawancara kepada infomen menurutnya upaya yang dilakuakan untuk menunjang prestasi anak adalah dengan dua cara. Cara (1) lewat keluarga, upaya yang dilakukan orang tua untuk meningkatkan prestasi belajar anaknya antara lain; (a) mengawasi kegiatan belajar atau mendampingi belajar dan penggunaan waktu belajar anak, (b) membeli buku-bukunya yang bervariasi, (c) bijaksana, kita sebagai orang tua perlu bersikap bijaksana untuk mengerti kemampuan yang dimilki anak; (2) melalui sekolah antara orang tua dan sekolah berkomunikasi melalui telpon.

\section{Informan Gt}

Ibu Gt aktif sebagai donatur untuk berbagai kegiatan sosial di lingkunganya. Ibu Gt yang berlatarbelakang pendidikan Syariah dari Perguruan Tinggi Islam juga memiliki kemampuan untuk berdakwah di mimbar. Sehingga pada saat-saat tertentu di celah-celah kesibukannya, ibu Gt juga masih sempat mengisi pengajian untuk ibu-ibu di Masjid. Dari berbagai kegiatan dan aktifitas yang dilakukan ibu Gt membuat ibu Gt menjadi seseorang yang tidak hanya dikenal sebagai orang yang memiliki kepedulian sosial yang tinggi, tetapi juga menjadi ibu yang diteladani di lingkungannya. Begitu juga dengan ibu Gt telah menjalankan pola pengasuhan dan melakukan pendidikan serta pembelajaran guna mengembangkan minat baca anak-anaknya. Ibu Gt memberikan penjelasan:

"Faktor pertama yang harus dimiliki oleh orang tua agar anaknya mau mengikuti kehendak. ataupun program yang baik bagi anak, adalah kemampuan orang tua dalam memahami. Sebab dengan memahami tersebut, orang tua menjadi mengerti situasi anak. Kadang-kadang kita kasihan juga dengan anak di sekolah dia sudah dibebani dengan sejumlah materi 
pelajaran. Kemudian di rumah, masih membawa tugas-tugas sekolah atau pekerjaan rumah yang juga banyak. Disamping itu, kita sebagai orang tua juga menginginkan anak mau membaca buku-buku di rumah selain buku pelajarannya dan menyediakan ruang belajar dilengkapi buku pusta. Jike situasi seperti itu tidak dipahami oleh orang tua anak bisa menjadi tertekan. Hal ini menimbulkan dampak yang tidak baik bagi perkembangan anak, baik psikis maupun fisiknya, emosional anak menjadi tidak stabil, anak juga cenderung stress. Akbirnya anak menjadi jenuh, jika suatu saat dia mendapatkan kebebasan, maka saat itulah memungkinkan dia susah untuk dikendalikan".

Keluarga Gt menerapkan pola pengasuhan demokratis dan situasional dalam kegiatan pengasuhan mereka. Ada perbedaan antara teori pola asuh dengan kegiatan pengasuhan yang diterapkan keluarga Gt. Perbedaan dan kelebihan dari kegiatan pengasuhan keluarga Gt ialah dengan memberikan kasih sayang mendalam kepada anak, memahami situasi dan kebutuhan anak, serta memberikan fasilitas perpustakaan dan ruang belajar di rumah mereka. Berdasarkan wawancara kepada informen, menurutnya upaya yang dilakuakan untuk menunjang prestasi anak adalah dengan dua cara. Cara (1) lewat keluarga, upaya yang dilakukan orang tua untuk meningkatkan prestasi belajar anaknya antara lain adalah (a) menyediakan ruang belajar, (b) Membeli buku-bukunya islami dan umum, (c) menanamkan kebiasaan positif; dan (2) melalui sekolah antara orang tua dan sekolah berkomunikasi melalui telpon menghadiri setiap ada undangan dari sekolah.

\section{Informan $\mathrm{Mr}$}

Mencermati pola kehidupan Bapak Mr dalam mengasuh dan mendidik anakanaknya, walaupun Bapak Mr sebagai pemilik toko dengan omset dan sirkulasi perdagangan yang pesat, sehingga menyita waktunya bersama anak-anak, Bapak $\mathrm{Mr}$ sangat peduli dengan pendidikan dan pembelajaran anak-anaknya, terutama dalam hal pendidikan agama. Di rumah Bapak Mr tersedia koleksi buku-buku yang banyak, semuanya buku-buku agama. Anak-anak Bapak Mr selalu diarahkan untuk membaca buku-buku tersebut.Penerapan yang dilakukan oleh Bapak Mr kepada anaknya yang tidak mengenal kata situasi anak, karena situasi itu orang tualah yang harus menciptakannnya. Model seperti itu agak sedikit melunak dengan penerapan yang dilakukan oleh Bapak, seperti yang dituturkannya:

Anak itukan makbluk. Allah berbentuk manusia, pasti memiliki keinganan dan memiliki perasaan. Tapi anak.jangan dibiarkan berbuat sekehendak hatinya maka sebaiknya diatur dan dirancang jadwal belajar dan harus dilaksanakan jika tidak diberi bukuman. Di satu sisi seperti itulah anak, Dia memiliki keinginan juga memiliki perasaan, maka orang tua mesti mampu membaca keinginan dan perasaan anak. Orang tua yang baik barus menselaraskan minimal 3 hal penting: (1) Keinginan dan potensi anak, (2) Perasaan anak, (3) Keadaan dan kemampuan orang tua. Ketiga aspek ini harus diselaraskan dalam mendidik anak untuk mengembangkan minat bacanya. Keinginan dan potensi anak harus diperhatikan, kalau potensi ini mengarah kepada bidang olahraga. Sebaiknya orang tua 
menyediakan bahan-bahan bacaan yang berkenaan dengan olahraga. Sementara buku-buku agama merupakan buku wajib harus dibaca oleh anak, dengan model membacanya memperbatikan poin 2 (perasaan anak). Jangan anak terlalu diporsir diluar ukuran dan kemampuan seorang anak. Sementara itu untuk poin 3 seberapa pun tingginya keinginan orang tua dan hebatnya antusias anak, tentulah kemampuan orang tua juga harus diperhatikan dan dikompromikan kepada anak.".

Keluarga Mr menerapkan pola pengasuhan otoriter dalam kegiatan pengasuhan di rumah, terlihat dari adanya aturan dan batasan yang dibuat orang tua dan jika anak meanggar akan mendapat hukuman. Namun ada perbedaan antara teori pola asuh dengan kegiatan pengasuhan yang diterapkan keluarga Mr. Perbedaan dan kelebihan dari kegiatan pengasuhan keluarga Mr ialah tetap memberikan kasih sayang mendalam untuk anak dengan memahami dan memperhatikan perasaan serta keinginan anak melalui komunikasi. Berdasarkan wawancara kepada infomen menurutnya upaya yang dilakuakan untuk menunjang prestasi anak adalah dengan dua cara. Cara (1) lewat keluarga, upaya yang dilakukan orang tua untuk meningkatkan prestasi belajar anaknya antara lain: (a) menyediakan ruang belajar, (b) Membuat peraturan tata tertib ketika dirumah dan jadwal belajar, (c) menanamkan kebiasaan positif; (2) melalui sekolah antara orang tua dan sekolah berkomunikasi melalui telpon menghadiri setiap ada undangan dari sekolah.

\section{Informan Mp}

Bapak Mp, sebagai seorang PNS sukses yang sangat super sibuk dengan pekerjaannya, Bapak Mp sedikit memiliki pandangan yang berbeda dalam hal mendidik anak, terutama dalam pola pengasuhan untuk mengembangkan minat baca anak. Bagi bapak Mp yang paling penting anak terlayani dan terlindungi hak-haknya sebagai anakanak. Secara jelas Bapak Mp memberikan penjelasan:

"Iujur saya akui saya memang sangat sibuk dan memiliki waktu yang sedikit untuk anakanak. Tapi saya tetap memperbatikan tumbub kembang mereka terutama dalam hal pendidikan dan belajar mereka walaupun anaknya sudah di SD tetapi tetap mengasubnya dengan kasih dan sayang. Mengenai bahan bacaan untuk anak, bagi saya itu sudah menjadi kewajiban yang biasa harus diupayakan dan disediakan oleh orang tua untuk anak-anaknya. Hanya saja jenis buku-buku tersebut, kalau kepentingannya untuk. sekolah, tentu sudah ada aturan tersendiri dan kurikulum tersendiri yang wajib kita ikuti. Sedangkan untuk bacaan tambahan kalau saya selalu mendiskusikan dan bertanya maunya anak. Saya tidak bermasalah anak-anak membeli komik-komik maupun bukubuku cerita yang sesuai dengan usia dan keinginan mereka. Pola pemaksaan kehendak, agar anak mengikuti kehendak dan kemanan orang tua, saya pikir sudah bukan zamannya lagi".

Keluarga Mp menerapkan pola pengasuhan demokratis dan situasional dalam kegiatan pengasuhan mereka. Ada perbedaan antara teori pola asuh dengan kegiatan 
pengasuhan yang diterapkan keluarga Mp. Perbedaan dan kelebihan kegiatan pengasuhan keluarga Mp dengan memberikan kasih sayang mendalam kepada anak, memberikan kebebasan anak untuk memilih buku bacaan, dan berkomunikasi saat ada waktu libur. Berdasarkan wawancara kepada informan menurutnya upaya yang dilakuakan untuk menunjang prestasi anak adalah dengan dua cara. Cara (1) lewat keluarga, upaya yang dilakukan orang tua untuk meningkatkan prestasi belajar anaknya antara lain: (a) Bermusyawarah tidak memaksakan kehendak, (b) membeli buku-bukunya yang islami dan umum komik dan novel, (c) menanamkan kebiasaan positif; (2) melalui sekolah antara orang tua dan sekolah berkomunikasi melalui telpon menghadiri setiap ada undangan dari sekolah.

\section{Informan Nh}

Pemilihan sekolah yang dilakukan oleh ibu Nh untuk anaknya dengan pertimbangan agar anaknya menjadi mandiri, disatu sisi merupakan langkah bijak yang telah dipilihnya. Namun di sisi lain dengan kesibukannya yang padat ditambah suaminya juga bekerja di salah satu perusahaan, bahkan dengan sistem kerja on, off mengharuskan suami ibu Nh sering meninggalkan rumah dalam jangka waktu lama. Keadaan tersebut sesungguhnya dapat membawa dampak berkurangnya waktu untuk memperhatikan perkembangan psikis, pembelajaran serta pembinaan maupun pengasuhan kepada anak. Dalam kondisi seperti ini. Sementara itu bagi ibu Nh menerapkan model situasional kepada anak merupakan solusi yang terbaik seiring dengan pesatnya perkembangan teknologi komunikasi dan informasi. Lebih jauh ibu Nh memberikan penjelasan:

"Dizaman canggih sekarang ini, dengan lajunya percepatan teknologi komunikasi dan informasi, orang tua tidak dapat lagi menjadi satu-satunya penentu mutlak yang mewarnai kehidupan anak. Anak-anak dapat mengakses begitu banyak informasi lain selain yang diberikan oleh orang tua, maupun informasi-informasi yang didapatkan dari sekolah. Babkan tidak dapat dipungkiri, sekolah pun mengalami kalah cepat dengan lajunya perubahan dan perkembangan teknologi informasi dan komunikasi. Tapi jangan sampai anak tidak memiliki sikap seperti berbakti kepada orang tua, santun dan sayang kepada sesama, bersikap jujur, berani karena benar, tidak berbohong, bersabar, tekun bekerja, bersabaja, sederhana. Maka kaitannya dengan pengembangan minat baca anak. Orang tua harus mampu membaca situasi seperti itu. Bahwa bacaan tidak lagi berbentuk buku cetak, tetapi ati ating dari berbagai model dan bentuk. Jika orang tua mampu menyesuaikan dirinya dengan perkembangan dan perebuahan tersebut, maka anak akan senantiasa nyaman mengikuti arahan orang tua, sehingga kecintaannya untuk membaca tetap dapat ditumbuh-kembangkan".

Keluarga Nh menerapkan pola pengasuhan bersamaan antara pola pengasuhan demokratis dan situasional dalam kegiatan pengasuhan mereka. Ada perbedaan antara teori pola asuh dengan kegiatan pengasuhan yang diterapkan keluarga Nh. Perbedaan dan kelebihan kegiatan pengasuhan keluarga Nh ialah memberikan kasih sayang mendalam untuk anak, menegur anak dengan bahasa yang tidak menyakiti, serta 
memberikan fasilitas membaca dengan mempertimbangkan kemajuan teknologi. Berdasarkan wawancara kepada informen menurutnya upaya yang dilakuakan untuk menunjang prestasi anak adalah dengan dua cara. Cara (1) lewat keluarga, upaya yang dilakukan orang tua untuk meningkatkan prestasi belajar anaknya antara lain: (a) menyediakan ruang belajar, (b). Melengkapi fasilitas belajar seperti computer, print out, (c) menanamkan kebiasaan positif, dan (d) merawat pertumbuhan fisik melalui gizi teratur; (2) melalui sekolah antara orang tua dan sekolah berkomunikasi melalui telpon menghadiri setiap ada undangan dari sekolah.

\section{Informan Rf}

Bapak Rf ditengah kesibukan dan aktivitas bisnisnya yang padat, Bapak Rf memiliki cara tersendiri untuk mengetahui keberadaan dan aktivitas anak-anaknya di rumah. Dengan model seperti ini bagi Bapak Rf dia telah melakukan pengawasan dan penanaman nilai-nilai kebenaran dan nilai-nilai yang harus diterapkan oleh anak-anaknya. Disamping itu, Bapak Rf, memanfaatkan teknologi untuk melakukan pola asuh kepada anaknya. Situasi yang agak berbeda ternyata diterapkan oleh bapak Rf, sebagai seorang kontraktor kaya Bapak Rf mengatakan:

"Baginya memberikan kebebasan memilih secara demokratis, anak harus diajarkan sejak. dini kemampuan untuk berani melakukan tindakan pengambilan keputusan untuk dirinya. Karena itu, dalam rumah tangga bapak Rf memberikan penjelasan kepada anak, seperti apa baik buruknya, pendidikan seperti apa yang harus ditempuh, pembelajaran seperti apa yang harus diterapkan secara baik untuk masa depannya. Setelah penjelasan dan harapan saya sampaikan, lalu secara demokratis saya memberikan peluang kepada anak. untuk memilih dan menentukan jalan bidupnya sendiri”.

Keluarga Rf menerapkan pola pengasuhan demokratis dalam kegiatan pengasuhan mereka di rumah. Ada perbedaan antara teori pola asuh dengan kegiatan pengasuhan yang diterapkan keluarga Rf. Perbedaan dan kelebihan kegiatan pengasuhan keluarga Rf ialah adanya kegiatan pembiasaan kepada anak untuk berani dan bebas memutuskan pilihannya sejak dini, memberikan kasih sayang mendalam, mengajak dan mengarahkan anak mengungkapkan pendapat, serta menghargai pendapat semua orang dalam keluarga mereka. Dalam al-Qur'an surat al-Imran ayat 159 juga menjelaskan bahwa dalam pengasuhan hendaklah berlaku lemah lembut, memaafkan, mendo'akan dan bermusyawarah.

Berdasarkan wawancara kepada informen menurutnya upaya yang dilakuakan untuk menunjang prestasi anak adalah dengan dua cara. Cara (1) lewat keluarga, upaya yang dilakukan orang tua untuk meningkatkan prestasi belajar anaknya antara lain: (a) menyediakan ruang belajar, (b) memberikan peluang kepada anak untuk memilih dan menentukan, (c) Rekreasi, dan (d) menjaga gizi anak; cara (2) melalui sekolah antara orang tua dan sekolah berkomunikasi melalui telpon menghadiri setiap ada undangan dari sekolah 


\section{Informan Ry}

Ry adalah seorang ibu rumah tangga, awalnya pernah menjadi seorang dosen swasta, selanjutnya berhenti untuk memberikan waktu banyak terhadap anak-anaknya. Seorang ibu yang dengan ikhlas telah mengkhususkan waktu dan dirinya hanya untuk mengasuh dan merawat anak-anaknya. Dalam konteks model situasional untuk mengembangkan minat baca anak, ibu Ry memberikan persetujuannya, lebih lengkap ibu Ry memberikan penjelasan:

"Ya, ya memang harus begitu dalam mendidik anak, kita orang tua tidak boleh senantiasa memaksakan kehendak sesuai dengan keinginan kita, sebaliknya kita orang tua juga tidak boleh membiarkan semaunya anak. Maka antara keinginan harapan dan cita-cita kita kepada anak, harus kita sesuaikan dengan keinginan dan perasaan anak. Jika anak keinginannya membaca buku umum, kita sediakan buku umum, tetapi tetap kita selipkan buku-buku agama. Jika keinginan anak inginnya sekolah di pendidikan umum, kita cari sekolah yang menselaraskan antara pemberian materi pelajaran umum dengan mengedepankan materi-materi pelajaran agama, sehingga keinginan anak terpenubi. Sementara kewajiban orang tua mendidik anaknya secara agamis juga terpenubi. Model seperti ini telah diterapkan dalam proses pendidikan dan pembelajaran di SD Islam Ash-Shofa Pekanbaru”.

Keluarga Ry menerapkan pola pengasuhan demokratis dan situasional dalam kegiatan pengasuhan mereka. Ada perbedaan antara teori pola asuh dengan kegiatan pengasuhan yang diterapkan keluarga Ry. Perbedaan dan kelebihan kegiatan pengasuhan keluarga Ry terlihat dari memberikan kasih sayang mendalam kepada anak, adanya kegiatan berdiskusi dan saling terbuka dengan anak, tidak memaksakan kehendak dan harapan orang tua. Berdasarkan wawancara kepada informen, upaya yang dilakuakan untuk menunjang prestasi anak adalah dengan dua cara. Cara (1) lewat keluarga, upaya yang dilakukan orang tua untuk meningkatkan prestasi belajar anaknya antara lain: (a) Menyediakan ruang belajar, (b) membeli buku buku agama dan buku buku umum terutama buku paket, (c) menselaraskan keinginan dan harapan serta kemampuan, dan (d). menjaga gizi anak; dan cara (2) melalui sekolah antara orang tua dan sekolah berkomunikasi melalui telpon menghadiri setiap ada undangan dari sekolah dan mengikuti program orang tua mengajar

\section{Pembahasan}

Berangkat dari penjelasan yang dikemukakan serta yang telah diterapkan oleh informan penelitian, maka terlihatlah informan penelitian telah menerapkan pola situasional dalam mengasuh anaknya agar memiliki keinginan untuk mengembangkan minat baca sejak dini. Sedangkan satu orang informan tetap pada pendiriannya bahwa situasi bukan dilihat dari anak ataupun lingkungan tetapi orang tualah yang menentukan dan menciptakan situasi itu. Sementara itu, satu orang informan lagi lebih menekan pola pengasuhan kepada anak dengan memberikan penekanan kepercayaan kepada anak untuk dapat memilih dan menentukan secara demokratis. Sebagaimana yang dinyatakan 
oleh Lira ${ }^{8}$ Orang memulai membacakan buku untuk anak-anaknya untuk menunmbuhkan minat bacanya.

Berdasarkan uraian di atas, jika dicermati indikator pola asuh yang diterapkan keluarga muslim SD Ash-Shofa Pekanbaru Riau dalam mengembangkan minat baca anak, yang tergambar dalam empat pola, yakni (1) Pola asuh Otoriter, (2) Pola asuh Demokratis, (3) Pola asuh Permisif, (4) Pola asuh Situasional. Maka dari empat pola tersebut berdasarkan wawancara dan pendalaman langsung ke lapangan, terlihat pola yang mengerucut pada satu model pengembangan minat baca anak yang dilaksanakan oleh orang tua Muslim yang anaknya bersekolah di SD Islam Ash-Shofa Pekanbaru Riau. Bagaimana pola asuh yang dikembangkan oleh orangtua memberikan efek besar terhadap kebiasaan prilaku seorang anak ${ }^{9}$. Sehingga untuk menigkatkan minat baca anak perlu memperhatikan bagaimana orangtua mengasuh anak-anaknya.

Baumrind menyebutkan ada empat model sifat pola asuh orang tua, yakni pola otoriter, demokratis, permisif dan situasional ${ }^{10}$. Sedangkan Kerr, ${ }^{11}$ menekankan pada kebiasaan anak, kebiasaan yang dimiliki anak sebagian besar terbentuk oleh pendidikan keluarga karena sejak bangun tidur hingga saat tidur kembali, anak-anak menerima pengaruh dari lingkungan keluarga. Untuk anak sekolah dasar sebagian peneliti juga menyampaikan mengunakan metode memberikan kisah pada anak dalam mendidik mereka ${ }^{12}$. Menurut psikologi pendidikan islam ${ }^{13}$, ada hal yang penting bagi orang tua dalam hubungannya dengan anak, yakni mengetahui hakekat perkembangan anak sehingga mereka akan mengerti bagaimana anak berkembang dalam hal kognitif, afektif, moral, sosial. Orang tua yang mampu menciptakan iklim psikis yang gembira dan bahagia, maka suasana rumah tangga penuh dengan kehangatan, rasa aman, dan kasih sayang. Iklim psikologi penuh kasih sayang, kehangatan, dan rasa aman tersebut memberikan vitamin psikologis yang akan memberikan motivasi dalam pertumbuhan anak menuju kedewasaan.

${ }^{8}$ Ö. Ece Demir-Lira and others, 'Parents’ Early Book Reading to Children: Relation to Children’s Later Language and Literacy Outcomes Controlling for Other Parent Language Input', Developmental Science, 22.3 (2019) <https://doi.org/10.1111/desc.12764>.

9 Xiaowei Feng and others, 'Effects of Parental Autonomy Support and Teacher Support on Middle School Students' Homework Effort: Homework Autonomous Motivation as Mediator.', Frontiers in Psychology, 10 (2019), 612 <https://doi.org/10.3389/fpsyg.2019.00612>.

10 Sang Min Lee, M. Harry Daniels, and Daniel B. Kissinger, 'Parental Influences on Adolescent Adjustment: Parenting Styles Versus Parenting Practices', The Family Journal, 14.3 (2006), 253-59 $<$ https://doi.org/10.1177/1066480706287654>.

${ }^{11}$ Jeannie Kerr, 'Habituation: A Method for Cultivating Starting Points in the Ethical Life', Journal of Philosophy of Education, 45.4 (2011), 643-55 <https://doi.org/10.1111/j.1467-9752.2011.00826.x>.

12 Michael B. Horn, 'Online Learning Goes Hollywood: Using Video Storytelling to Motivate Learning', Education $\quad$ Next, $\quad 19.2 \quad$ (2019), $\quad 82-84$ <https://go.galegroup.com/ps/anonymous?id=GALE\%7CA579994802\&sid=googleScholar\&v=2.1\&it $=\mathrm{r} \&$ linkaccess $=$ abs\&issn $=15399664 \& \mathrm{p}=\mathrm{AONE} \& \mathrm{sw}=\mathrm{w}>$ [accessed 28 October 2019].

13 Irliana Faiqotul Himmah, Fuad Hasan, and A.T. Hendrawijaya, 'The Optimization of Iqro' Method Implementation in Basic Functional Literacy Learning by Developing Learning Material Based Padi (Rice Plant) as One of Local Potency in Jember', in Proceedings of the 1st Non Formal Education International Conference (NFEIC 2018) (Paris, France: Atlantis Press, 2019) < https://doi.org/10.2991/nfeic18.2019.9>. 
Menelusuri dan mengarahkan minat baca anak sejak dini merupakan keharusan yang mesti dilakukan oleh orangtua di dalam keluarga. Orang tua dapat dengan cepat dan mudah mengarahkan anaknya sesuai dengan minat dan potensi yang dimiliki oleh anak. Sumbangan orang tua dalam keluarga bagi pendidikan anak yang paling mendasar adalah: (1) Cara orang tua melatih anak untuk menguasai cara-cara mengurus diri, seperti makan, buang air, berbicara, berjalan, berdoa, sungguh-sungguh membekas dalam diri anak karena berkaitan erat dengan perkembangan dirinya sebagai pribadi; (2) Sikap orang tua sangat mempengaruhi perkembangan anak. Sikap menerima atau menolak, sikap kasih sayang atau acuh tak acuh, sikap sabar atau tergesa-gesa, sikap melindungi atau membiarkan secara lansung mempengaruhi reaksi emosional anak ${ }^{14}$.

Sumadi Suryabrata ${ }^{15}$ menyatakan bahwa hal yang mempengaruhi minat baca anak adalah; (1) Perasaan senang terhadap suatu objek; (2) Perhatian terhadap objek; (3) Bakat, yang dalam psikologi disebut potensialitas atau disposisi; (4) Cita-cita; dan (5) kemauan, adanya kemauan yang kuat berarti seseorang telah memiliki modal yang kuat untuk mencapai tujuan. Minat dapat pula dipengaruhi oleh faktor kondisi rangsangan seperti pengalaman, karakter individu, variasi situasional, perbedaan individu, dan karakter tokoh panutan yang muncul dalam bentuk informasi dasar. Informasi dasar adalah konsekuensi keyakinan, evaluasi, motivasi, sikap terhadap perilaku dan normanorma subjektif. Dengan demikian secara teoritis, dapat dijelaskan bahwa antara sikap, minat dan perilaku menjadi satu model yang saling berkaitan untuk dapat tumbuhnya minat baca.

Mencermati uraian teori dan pendapat ahli di atas memberikan pemahaman bahwa tumbuhnya minat baca pada anak dapat dipengaruhi oleh banyak hal dan peristiwa serta peranan penting dari pola yang diterapkan orang tua. Semua faktor tersebut saling berkaitan dalam mendorong tumbuhnya minat anak baik dari dalam dirinya maupun dari luar individu anak. Karena itu, orang tua sangat dituntut untuk memiliki wawasan dan ilmu pengetahuan yang luas dalam rangka mengaplikasikan konsep-konsep, teori-teori yang dapat menunjang minat baca anak.

Elizabet B. Hurlock, ${ }^{16}$ menyinggung minat baca anak. Ada empat hal yang mendasari kenapa minat baca perlu dikembangkan sedini mungkin. Pertama, hasil belajar dari pengalaman awal mempunyai peran dominan dalam perkembangan dan usia anak, serta bimbingan awal yang baik akan menjadi fondasi bagi anak; Kedua, dasar awal akan berkembang menjadi kebiasaan; Ketiga, pola sikap dan perilaku yang dibentuk pada awal terhadap anak cenderung bertahan; Keempat, perubahan yang cepat dan bijaksana oleh orang yang dekat dengan anak akan membuat anak mau bekerja sama dalam mengadakan perubahan. Sementara Crow dan Crow ${ }^{17}$, menekankan pada aspek timbulnya rasa suka atau minat anak. Minat merupakan kekuatan pendorong (motivation

${ }^{14}$ Hasbullah, Dasar-Dasar Ilmu Pendidikan (Jakarta: Rajawali Press, 2013).

15 Sumadi Suryabrata, Bimbingan Konseling Di Sekolah (Jakarta: RajaGrafindo Persada, 1989).

${ }^{16}$ Elizabet B. Hurlock, Child Development (New York: MC.Graw. Hill, INC, 1978).

${ }^{17}$ Lester D. Crow and Alice Crow, Child Development and Adjustment: Study of Child Psychology. (New York: MacMillan Co, 1962) <https://doi.org/10.1037/14399-000>. 
force) yang menyebabkan seseorang menaruh perhatian pada ruang lain atau objek lain. Hal ini dapat sebagai sumber motivasi untuk melakukan apa yang mereka inginkan bila mereka bebas memilih. Tiga faktor yang mempengaruhi timbulnya minat adalah; pertama dorongan dari dalam diri individu; kedua motif sosial; terakhir adalah faktor emosional.

Mendidik anak-anaknya merupakan tanggungjawab mutlak yang harus dilaksanakan orang tua yang tidak dapat ditukar ataupun digantikan oleh pihak manapun, karena di dalam tanggungjawab ini memerankan berbagai fungsi. Menurut Ahmad Tafsir ${ }^{18}$, tanggungjawab terpenting di dalam memberikan pendidikan keluarga dapat berbentuk: (a) Tanggungjawab bagi pelaksanaan pendidikan keimanan anak, (b) Tanggungjawab pengembangan moral anak, (c) Tanggungjawab perkembangan fisik anak, (d) Tanggungjawab intelektual anak, (e) Tanggungjawab psikologi anak, (f) Tanggungjawab perkembangan sosial anak, (g) Tanggungjawab seks. Melalui pendidikan yang dilaksanakan dalam keluarga akan menumbuhkan berbagai motivasi dalam diri anak. Sehingga anak benar-benar mendapatkan situasi sosial yang baik di dalam rumahnya.

Sebagai satu kesatuan hidup bersama (sistem sosial) keluarga terdiri dari ayah, ibu dan anak. Adanya ikatan kekeluargaan yang kuat dapat membantu anak mengembangkan sifat persahabatan, cinta kasih, hubungan antarpribadi, kerjasama, disiplin, tingkah laku yang baik, serta pengakuan akan kewibawaan. Sementara itu berkenaan dengan keluarga yang menyediakan situasi belajar, dapat dilihat bahwa bayi dan anak-anak sangat bergantung kepada peran orang tua. Baik keadaan jasmaniahnya maupun kemampuan intelekutal, sosial dan moral. Bayi dan anak belajar menerima dan meniru apa yang diajarkan oleh orang tua ${ }^{19}$. Pendapat ini memberikan pemahaman bahwa dalam pelaksanaan pendidikan, keluarga sangat dibutuhkan keharmonisan komunikasi ${ }^{20}$.

Adanya komunikasi yang baik dalam keluarga sebagai upaya untuk menumbuhkembangkan peri kehidupan sosial, psikolgi dan juga segala hal yang berhubungan dengan kebutuhan anak, termasuk untuk mengarahkan minat baca anak dalam rangka pengembangan pendidikan mental sosialnya. Selain itu, kekuatan komunikasi mampu menembus berbagai sekat dalam pelaksanaan pendidikan dalam keluarga. Sehingga setiap permasalahan dan hambatan yang terjadi bisa dengan cepat dapat terdeteksi untuk ditemukan jalan keluarnya. Termasuk menemukan minat anak ataupun mengarahkan anak agar berminat terhadap sesuatu, terutama berminat untuk mengetahui banyak hal melalui sumber bacaan.

18 Ahmat Tafsir, Epistemologi Untuk Ilmu Pendidikan Islam (Bandung: Fakultas Tarbiyah IAIN Bandung, 1996).

${ }^{19}$ Hasbullah.

20 Syaiful Bahri Djamarah, Pola Asuh Orang Tua Dan Komunikasi Dalam Keluarga (Jakarta: Rineka Cipta, 2014). 
Keluarga sangat berperan penting untuk mengarahkan minat anak dalam mengembangkan kemampuan dirinya. Karena itu menurut Chaplin ${ }^{21}$ dalam kamus psikologi menyebutkan bahwa interes atau minat dapat diartikan; (a) Suatu sikap yang berlangsung terus-menerus yang memberi pola perhatian seseorang sehingga membuat dirinya selektif terhadap objek minatnya; (b) Perasaan yang menyatakan bahwa suatu aktivitas, pekerjaan, objek itu berharga bagi individu, (c) Suatu keadaan motivasi yang menuntut tingkah laku menuju satu arah tertentu ${ }^{22}$.

Winkel menyatakan minat adalah kecenderungan yang agak menetap dan subjek merasa senang berkecimpung dalam bidang itu. Perasaan senang itu biasanya akan menimbulkan minat apalagi bila diperkuat dengan sikap positif, minat akan berkembang dengan lebih baik ${ }^{23}$. Secara tegas dapat dikatakan jenis pribadi anak sebagian besar sangat dipengaruhi minat yang berkembang selama masa kanak-kanak. Minat dapat memainkan peran yang sangat strategis bagi manusia dalam merumuskan arah kehidupannya. Minat mampu mencerminkan perilaku dalam seharian kehidupan, baik orang dewasa maupun anak-anak. Oleh karena itu, mengarahkan dan membimbing anak-anak agar menemukan minat dirinya ${ }^{24}$ menjadi penting untuk dilakukan oleh orang tua

Tumbuhnya minat baca tidak berdiri sendiri akan tetapi masih berhubungan dengan aspek lain. Minat betul-betul muncul apabila objek yang menjadi fokus minat mempunyai nilai (value) yang berhubungan dengan kebutuhan dan kemunculannya tersebut dalam rangka melakukan fungsi pengetahuan, penyesuaian diri serta aktualisasi diri. Menurut Sri Hastuti ${ }^{25}$ ada beberapa hal yang mempengaruhi minat baca anak diantaranya adalah: (1) kebutuhan anak; (2) kebutuhan dasarnya, yaitu rasa aman, status dan kedudukan tertentu, kepuasan efektif, kebebasan yang sesuai dengan kenyataan serta tingkat perkembangan; (3) didorong oleh status sosial ekonomi keluarga; (4) sarana dan prasarana dalam keluarga; 5) Perbedaan jenis kelamin secara psikologis juga mempengaruhi minat baca anak.

Dalman ${ }^{26}$ menyebutkan bahwa minat baca, sangat ditentukan oleh beberapa faktor. Pertama aktor lingkungan keluarga; Kedua faktor kurikulum dan pendidikan sekolah yang kurang kondusif; Ketiga faktor infrastruktur masyarakat yang kurang mendukung peningkatan minat baca masyarakat (kurangnya minat baca masyarakat ini bisa dilihat dari kebiasaan sehari-hari); dan keempat faktor keberadaan dan

21 James Patrick Chaplin, 'Dictionary of Psychology', Eweb:1638, 1968 <https://repository.library.georgetown.edu/handle/10822/1031264> [accessed 28 October 2019].

22 Jutta Heckhausen and Heinz Heckhausen, 'Motivation and Action: Introduction and Overview', in Motivation and Action (Cham: Springer International Publishing, 2018), pp. 1-14 <https://doi.org/10.1007/978-3-319-65094-4_1>.

${ }_{23}$ W.S.Winkel and M.M. Sri Hastuti, Bimbingan Dan Konseling Di Institusi Pendidikan (Yogyakarta: Media Abadi, 2013).

24 Daphna Oyserman, 'The Essentialized Self: Implications for Motivation and Self-Regulation', Journal of Consumer Psychology, 29.2 (2019), 336-43 < https://doi.org/10.1002/jcpy.1093>.

25 Sri Hastuti, 'Kemampuan Berbahasa Indonesia Murid SD Kelas', Laporan Penelitian Universitas Negeri Yogyakarta, 1980, 27.

${ }^{26}$ Dalman, Keterampilan Membaca (Jakarta: RajaGrafindo Persada, 2013). 
keterjangkauan bahan bacaan. Orang tua tidak hanya sebatas menginginkan anaknya mempunyai minat baca yang tinggi sedini mungkin, tetapi orang tua harus benar-benar memahami pola yang diterapkan. Orang tua harus memposisikan dirinya agar berperan utuh dan mutlak dalam mengoptimalkan tumbuhnya minat baca anak. Orang tua tampil sebagai pendukung yang memberikan wadah dan menampung keinginan kesenangan anak terhadap bacaan dengan seluas-luasnya.

Hal terpenting yang harus dilakukan orang tua adalah menciptakan pola asuh menjadi senang ${ }^{27}$ dengan bahan bacaan. Di samping itu orang tua perlu kehatian-hatian agar maksud baik yang diinginkan tidak menjadi sebab anak malas bahkan anti dengan bahan bacaan. Pentingnya pola asuh yang tepat untuk meningkatkan minat baca anak dan besarnya dampak pola asuh yang kurang tepat untuk menimbulkan minat baca anak mejadikan hal ini dikaji. Sehingga hal itu sangat perlu digali informasi dari orang tua model pola asuh yang diterapkan dalam mendidiknya yang dapat memberikan konstribusi berarti dalam menumbuhkan atau sebaliknya mematikan minat baca anak.

\section{Catatan Akhir}

Berdasarkan uraian di atas dapat dikemukakan bahwa peranan pola asuh orangtua dalam keluarga sangat penting untuk menumbuhkan minat baca anak. Namun hal itu masih kurang efektif jika peranan pendidikan tidak berkualitas dan infrastruktur masyarakat yang rendah, yakni kurang kesadaran untuk membudayakan membaca dengan menyediakan perpustakaan di daerah masing-masing sehingga bahan bacaan lebih mudah untuk dijangkau.

Pola asuh yang biasa digunakan oleh orangtua adalah pola asuh demokratis dan pola asuh situasional. Hal ini menunjukkan bahwa untuk mengajak siswa rajin membaca orangtua seharusnya mengajaknya berdiskusi, mengamati dan juga tidak lepas dari perhatian dan kasih sayang orangtua. Selain itu, penelitian ini juga menunjukkan betapa orangtua sangat perlu meluangkan waktunya untuk anak-anak apalagi di usia SD. Temuan penelitian ini memberikan sumbangan terhadap para orangtua sekaligus pemerhati pendidikan untuk mendidik anak-anaknya dengan kasih sayang dan perhatian penuh. Dengan arti lain kualitas hubungan orangtua dan anak serta kelekatan antara keduanya serta integrasi orangtua dengan sekolah merupakan kunci kesuksesan dalam mendidik anak-anak. Sehingga secara psikologis dapat disampaikan upaya untuk meningkatkan minat baca anak dilakukan dengan meningkatkan kehangatan hubungan orangtua dan anak-anak.

\section{Daftar Rujukan}

Achmadi, Islam Sebagai Paradigma Ilmu Pengetahuan (Yogyakarta: Aditya Media, 1992)

Burris, Christopher T., and Rebecca Leitch, 'Harmful Fun: Pranks and Sadistic Motivation', Motivation and Emotion, $42.1 \quad$ (2018), 90-102 <https://doi.org/10.1007/s11031-017-9651-5>

${ }_{27}$ Christopher T. Burris and Rebecca Leitch, 'Harmful Fun: Pranks and Sadistic Motivation', Motivation and Emotion, 42.1 (2018), 90-102 <https://doi.org/10.1007/s11031-017-9651-5>. 
Chaplin, James Patrick, 'Dictionary of Psychology', Eweb:1638, 1968 <https://repository.library.georgetown.edu/handle/10822/1031264> [accessed 28 October 2019]

Chen, Qishan, Yurou Kong, Wenyang Gao, and Lei Mo, 'Effects of Socioeconomic Status, Parent-Child Relationship, and Learning Motivation on Reading Ability.', Frontiers in Psychology, 9 (2018), 1297 <https://doi.org/10.3389/fpsyg.2018.01297>

Chiu, Ming Ming, 'Contextual Influences on Girls' and Boys' Motivation and Reading Achievement: Family, Schoolmates, and Country' (Springer, Cham, 2018), pp. 4963 <https://doi.org/10.1007/978-3-319-75948-7_3>

Crow, Lester D., and Alice Crow, Child Development and Adjustment: Study of Child Psychology. (New York: MacMillan Co, 1962) < https://doi.org/10.1037/14399$000>$

Dalman, Keterampilan Membaca (Jakarta: RajaGrafindo Persada, 2013)

Djamarah, Syaiful Bahri, Pola Asub Orang Tua Dan Komunikasi Dalam Keluarga (Jakarta: Rineka Cipta, 2014)

Ece Demir-Lira, Ö., Lauren R. Applebaum, Susan Goldin-Meadow, and Susan C. Levine, 'Parents' Early Book Reading to Children: Relation to Children's Later Language and Literacy Outcomes Controlling for Other Parent Language Input', Developmental Science, 22.3 (2019) <https://doi.org/10.1111/desc.12764>

Feng, Xiaowei, Ke Xie, Shaoying Gong, Lei Gao, and Yang Cao, 'Effects of Parental Autonomy Support and Teacher Support on Middle School Students' Homework Effort: Homework Autonomous Motivation as Mediator.', Frontiers in Psychology, 10 (2019), 612 <https://doi.org/10.3389/fpsyg.2019.00612>

Fırat, Mehmet, Hakan Kilınç, and Tevfik Volkan Yüzer, 'Level of Intrinsic Motivation of Distance Education Students in E-Learning Environments', Journal of Computer Assisted Learning, 34.1 (2018), 63-70 <https://doi.org/10.1111/jcal.12214>

Hamka, Rusydi, and Iqbal Emsyarif Saimima, Kebangkitan Islam Dalam Pembahasan (Jakarta: Nurul Islam, 1980)

Hasbullah, Dasar-Dasar Ilmu Pendidikan (Jakarta: Rajawali Press, 2013)

Hastuti, Sri, 'Kemampuan Berbahasa Indonesia Murid SD Kelas', Laporan Penelitian Universitas Negeri Yogyakarta, 1980, 27

Heckhausen, Jutta, and Heinz Heckhausen, 'Motivation and Action: Introduction and Overview', in Motivation and Action (Cham: Springer International Publishing, 2018), pp. 1-14 <https://doi.org/10.1007/978-3-319-65094-4_1>

Himmah, Irliana Faiqotul, Fuad Hasan, and A.T. Hendrawijaya, 'The Optimization of Iqro' Method Implementation in Basic Functional Literacy Learning by Developing Learning Material Based Padi (Rice Plant) as One of Local Potency in Jember', in Proceedings of the 1st Non Formal Education International Conference (NFEIC 2018) (Paris, France: Atlantis Press, 2019) <https://doi.org/10.2991/nfeic18.2019.9>

Horn, Michael B., 'Online Learning Goes Hollywood: Using Video Storytelling to Motivate Learning', Education Next, $19.2 \quad$ (2019), 82-84 <https://go.galegroup.com/ps/anonymous?id=GALE\%7CA579994802\&sid=go ogleScholar\&v $=2.1 \& i t=r \&$ linkaccess $=$ abs\&issn $=15399664 \& \mathrm{p}=\mathrm{AONE} \& \mathrm{sw}=\mathrm{w}>$ [accessed 28 October 2019]

Hurlock, Elizabet B., Child Development (New York: MC.Graw. Hill, INC, 1978)

Kerr, Jeannie, 'Habituation: A Method for Cultivating Starting Points in the Ethical Life', Journal of Philosophy of Education, 45.4 (2011), 643-55 
<https://doi.org/10.1111/j.1467-9752.2011.00826.x>

Lee, Sang Min, M. Harry Daniels, and Daniel B. Kissinger, 'Parental Influences on Adolescent Adjustment: Parenting Styles Versus Parenting Practices', The Family Journal, 14.3 (2006), 253-59 <https://doi.org/10.1177/1066480706287654>

Mardiah, 'Menumbuhkan Minat Baca | IBLiMS', IBLiMs, 2014 <http://bpsdmkp.kkp.go.id/apps/perpustakaan/?q=node/23> [accessed 28 October 2019]

Mutia, Anissa, and Endro Yuwanto, 'Minat Baca Anak Indonesia Memprihatinkan | Republika Online', Republika, 2010 <https://www.republika.co.id/berita/pendidikan/berita/10/07/07/123680minat-baca-anak-indonesia-memprihatinkan> [accessed 28 October 2019]

Oyserman, Daphna, 'The Essentialized Self: Implications for Motivation and Self-Regulation', Journal of Consumer Psychology, 29.2 (2019), 336-43 <https://doi.org/10.1002/jcpy.1093>

Suryabrata, Sumadi, Bimbingan Konseling Di Sekolab (Jakarta: RajaGrafindo Persada, 1989)

Tafsir, Ahmat, Epistemologi Untuk Ilmu Pendidikan Islam (Bandung: Fakultas Tarbiyah IAIN Bandung, 1996)

Ülger, Mehmet, Süleyman Yiğittir, and Orhan Ercan, 'Secondary School Teachers' Beliefs on Character Education Competency', Procedia - Social and Behavioral Sciences, 131 (2014), 442-49 <https://doi.org/10.1016/J.SBSPRO.2014.04.145>

W.S.Winkel, and M.M. Sri Hastuti, Bimbingan Dan Konseling Di Institusi Pendidikan (Yogyakarta: Media Abadi, 2013) 